\title{
Exclusive language: The tool to empower and create identity
}

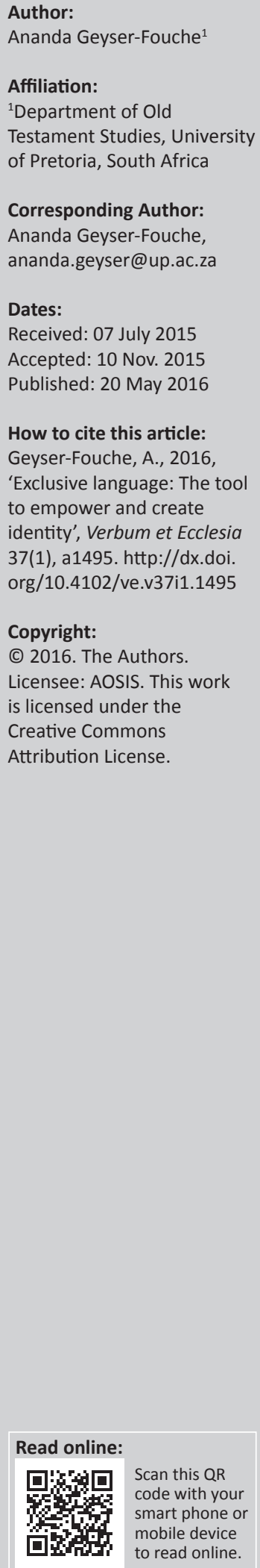

This article used some postmodern literary theories of philosophers such as Jean-François Lyotard, Michel Foucault, Jacques Derrida and Julia Kristeva to scrutinise a selection of texts from the post-exilic period with regard to the exclusive language employed in these texts. Lyotard's insights relate to and complement Foucault's concept of 'counter-memory'. Foucault also focuses on the network of discursive powers that operate behind texts and reproduce them, arguing that it is important to have a look from behind so as to see which voices were silenced by the specific powers behind texts. The author briefly looked at different post-exilic texts within identity-finding contexts, focusing especially on Chronicles and a few Qumran texts, to examine the way in which they used language to create identity and to empower the community in their different contexts. It is generally accepted that both the author(s) of 1 \& 2 Chronicles and the Qumran community used texts selectively, with their own nuances, omissions and additions. This study scrutinised the way the author(s) of Chronicles and the Qumran community used documents selectively, focusing on the way in which they used exclusive language. It is clear that all communities used such language in certain circumstances to strengthen a certain group's identity, to empower them and to legitimise this group's conduct, behaviour and claims - and thereby exclude other groups.

Intradisciplinary and/or interdisciplinary implications: Based on postmodern literary theories, this article compares the exclusive language used in Chronicles and in the texts of the Qumran community, pointing to the practice of creating identity and empowering through discourse. In conclusion, the article reflects on what is necessary in a South African context, post-1994, to be a truly democratic country.

\section{Introduction}

Twenty-one years of democracy. A cause for celebration, but also a call for introspection. Is South Africa truly a democratic ${ }^{1}$ country? Because an undemocratic country is characterised by (amongst other things) habits of exclusive language, I decided to look at the way exclusive language is used in ancient religious texts. I briefly look at different post-exilic texts within contexts that grapple with finding identity, focusing especially on Chronicles and a few Qumran texts, to examine the way in which they have used language to create identity and to empower the community in their different contexts.

I refer to aspects of the postmodern literary theories of philosophers such as Jean-François Lyotard, Michel Foucault, Pierre Bourdieu and Jacques Derrida to examine the exclusive language in texts, more specifically in Chronicles and a number of Qumran texts.

Lyotard's insights relate to and complement Foucault's concept of 'counter-memory'. Foucault also focuses on the network of discursive powers behind texts - the powers that reproduce texts and argues that it is important to have a look from behind to see which voices were silenced by the powers behind texts. For Bourdieu, language is not only a system for communicating, but also an instrument of power. ${ }^{2}$

\footnotetext{
1. With 'democracy' I refer to the concept that evolved as a reaction against the abuse of power. Democracy is seen as the idea of equal opportunities - freedom of speech that develops from empowering people and not overpowering them. Democracy is non-descriptive with regard to association, religion and culture and is in general inclusive. In this regard, I want to refer to Cilliers Breytenbach's (2015:4) quote of Van Zyl-Slabbert (2006:163), where he described the liberal democratic constitution of South Africa: ' $[I t]$ is not the celebration quote of Van Zyl-Slabbert (2006:163), where he described the liberal democratic constitution of South Africa: ' $I t]$ is not the celebration rights etc. form such a distinctive part of a liberal democracy'. Breytenbach (2015:4) says further that democracy is for him 'to nourish a culture where the loyalty to the sanctity of the person and respect for his or her basic rights outweighs the loyalty to political, ethnic, racial or religious alliances ... All political parties have the duty to contribute to lawful legislation that respects the fundamental rights of all citizens as entrenched in the constitution'. Schmitter and Karl (1991:76) argue that democracy entails the fact that rulers can be held accountable: 'Modern political democracy is a system of governance in which rulers are held accountable for their actions in the public realm by citizens, acting indirectly through the competition and cooperation of their elected representatives'.
}

Note: This article is a revision of a paper that I delivered at the OTSSA conference in 2014. The theme of the conference was 'Studying the Old Testament in South Africa from 1994 to 2014 and beyond'. 
It is generally accepted that both the author(s) of 1 and 2 Chronicles and the Qumran community used texts selectively, with their own nuances, omissions and additions.

I examine the way the author(s) of Chronicles and the Qumran community used documents selectively by focusing on the way in which they used exclusive language in their distinctive contexts.

In conclusion, I contextualise the exclusive and inclusive language as it is appropriated in different communities and reflect on the question of whether South Africa is truly democratic after 21 years of democratic elections.

\section{Theoretical framework}

In order to understand what I mean by the term 'exclusive language', it is necessary to look at the development of thought on language as an instrument. Therefore, this section will briefly discuss this development, especially in the postmodern paradigm $^{3}$ and particularly in relation to power. Although Foucault (and other philosophers like him) never used the term 'postmodern' and insisted that he should not be understood within any kind of structure or paradigm, his thoughts were part of a paradigm shift that took place after modernity and post-structuralism. ${ }^{4}$

Beukes (2012:4) refers to Foucault's (1977:29) ${ }^{5}$ perception of understanding. Foucault says that everything that we attempt to understand is continuously and systematically configuring the connections with power and suppressing these into something else and that in the process of understanding, we are misled by those configurations and the masking of power. According to Foucault, all forms of knowledge create and interpret whilst participating in reality from a certain context and tradition. Therefore, no form of knowledge can be seen as exploring and documentary. Beukes (2012:16) explains that for Foucault, power has never arrived or is never completed but continues indefinitely. In essence, Foucault sees power as the relations between persons, where one person affects the other's conduct.

Bourdieu (1991:37; cf. also 68,107-109,130-139) sees language as not only a system for communicating but also an instrument of power. A person's relational position in a field or social space determines his or her language (Bourdieu 1991:80). For example, a certain accent can reveal someone's origin (Bourdieu 1991:1; cf. also 264). This means that the relevant social paradigm determines whose opinion is accepted as reliable, who can be listened to, who may ask questions and who may not (Bourdieu 1991:215; cf. also 233, 238, 243-249). Through forms of rational depictions, with signs and symbols, language acts as an instrument of power

3.This study will not attempt to give any clear-cut ideas on which philosopher represents which paradigm, but will rather use some ideas that originate from the post-structuralist legacy of literary philosophers, especially those that pertain to the power(s) behind language and exclusive language.

4.Refer to Beukes' (2012:1) explanation of Foucault's resistance to being categorised into having any method of departure.

5.See also Foucault $(1979,1984)$.
(Bourdieu 1991:68). Bourdieu (1995) also refers to the reaction that the abuse of power has in language:

The same intention of autonomy can in effect be expressed in opposite position-takings (secular in one case, religious in another) according to the structure and the history of the powers against which it must assert itself. (p. 343)

Keane (1992) says that the problem of legitimacy is of special interest to Lyotard. Keane (1992:85) explains it as the process 'by which every particular language game seeks to authorize its "truth", "rightness" and (potential) efficacy - and therewith its superiority over others'. He explains that every utterance in a language game should be understood as a move with or against other players and that these language games are always rooted in matters of power - 'power here understood as the capacity of actors wilfully to block or to effect changes in speech activities of others' (Keane 1992:86). These language games he also classifies as 'definite social practices', in the sense that they aim to produce, reproduce or transform forms of social life (cf. Benjamin 1992).

Dews (1984:40), referring to Foucault, says that 'normative thought can only operate in the interest of power'. Perdue (2005:239) quotes Foucault, saying, 'There is no power relation without the correlative constitution of a field of knowledge, nor any knowledge that does not presuppose and constitute at the same time power relations'.

Beukes (1996:235) explains Foucault's opinion about reason. According to Foucault, reason will always exclude and include only selectively. Beukes (1996:236) says that for Foucault reasoning will be authentic when it succeeds in not excluding, but where the other (the historically minimised) segments of truth will be realised, recognised and included.

Exclusive language will thus be the discourse used in certain circumstances to strengthen a certain group's identity and to empower it; to legitimise the group's conduct, behaviour and claims and in the process to exclude other groups. It is important to note that exclusive language is not always uttered speech or of an emphatic nature but can also lie in what has not been said. Exclusive language can often be seen in what is underplayed or what is clearly left out in the narration.

\section{Exclusive language used in different post-exilic texts and identity-finding contexts}

Quite a number of Old Testament studies have recently been conducted with regard to identity finding in Israel, especially focusing on the post-exilic era, known as the time of the Second Temple. ${ }^{6}$

6.See inter alia Adams (2014): Brett (2010): Leuchter (2010): Jonker (2003, $2010 \mathrm{c}$ 2010b), all the essays in Jonker (2010a); Mitchell (2010); Person (2010); all the essays in Ben Zvi and Edelman (eds. 2014); Blenkinsopp (2013); García Martínez (2007d:189-192) for a discussion on the development in the meaning of the term 'Israel'; and Newsom (2004). 
Jonker (2010c) says inter alia that:

texts are not mere reflections of well-defined identities, but are rather part of ongoing identity negotiation processes. This applies pertinently to texts originating in contexts of transition, such as the post-exilic period under Persian rule in Yehud. (p. 600)

Bosman (2014:1) also refers to Israel's need to find an identity after the exile. To this end, he argues, it was crucial for them to rely on their collective memory. As Blenkinsopp (2009:32) states, 'As long as the kingdom of Judah lasted, the identity of those who belonged to it was unproblematic'.

The Babylonian exile and its repercussions in the Persian period dramatically changed the position of Israel. Before the exile, the people's identity and self-understanding were strongly related to the Davidic monarchy. After the exile, almost everything changed. It all began with Cyrus' decree in 538 BCE (cf. Ezr 1 and 2 Chr 36), which released the exiles to return to their land and even sanctioned the rebuilding of the temple with monetary funding from the empire. Whilst still dreaming of the revival of the Davidic monarchy, the people were forced to accept the inevitability of becoming a province (named Yehud) under Persian imperial rule. These events led to a total transformation of the sociopolitical and sociocultural milieu, causing changes in the processes of identity negotiation in Israel. Their visions during the exile of freedom under a Davidic king did not concretise; instead, they were subjects under a Persian emperor who acknowledged their traditional and religious aspirations (cf. Jonker 2010c:594-599). Jonker (2010c:599) says that it is no surprise that this was the most fruitful time of theological reflection in Israel's history, resulting in many of the biblical writings that are contained in the Old Testament'.

Most of the studies pertaining to Judah's identity finding in the Second Temple era reveal that the nation was confused and in disarray after the exile; and by distancing themselves from the 'Other' (whether the 'Other' indicated other nations or other ideologies or sects within Judaism), the people attempted to create an identity for themselves. Most scholars studying the identity finding of Israel in post-exilic times agree that this particular period was a time when this nation with diverse ideologies was seeking an identity. Most sought it by using exclusive language; very few attempted it by using inclusive language.?

\section{Exclusive language in Qumran texts}

The Qumran community ${ }^{8}$ is known as a sect that developed out of an apocalyptic movement (García Martínez 2007a:195; see also Vermes 1977:116). There is not enough space to discuss

7.1 will refer briefly to a few of these occurrences at the end of this study.

8.Talmon (1994:17) emphasises the unique character of this community: '[T] he Community of the Renewed Covenant should be viewed as a socioreligious phenomenon sui generis [italics in original] which cannot be identified with any phenomenon sui generis [italics in original] which cannot be identified with an subdivision of Second Temple Judaism of which the classical sources speak. Similarities of the yahad's ritual laws with Zadokite or Sadducee halakhah, of its communal structure with that of the Essenes, of the Covenanters legalistic outlook with that of the Samaritans, or of their religious vocabulary which at times overlaps with the creedal terminology of primitive Christianity - these similarities resulted from a common fund of traditions rooted in the Hebrew Bible, which was the heritage of all or most configurations of Judaism at the turn of the era'. 'apocalyptic movement' ${ }^{\prime}$ or 'sect'10 in this study. As both concepts are catalysts for exclusiveness, I will highlight only some of their common aspects.

Baumgarten (1997) discusses the Jewish sects that flourished in the Maccabean era. He points out that there are different types of sects and that when sects from this era are discussed, some common aspects must be taken into consideration (Baumgarten 1997:6). One is the 'voluntary nature of sectarianism', another is that sects protest 'against the practice and beliefs of the rest of society', and thirdly, there is the tendency of a sect to 'define itself by purity rules'. Baumgarten (1997) defines a sect as:

a voluntary association of protest, which utilizes boundary marking mechanisms - the social means of differentiating between insiders and outsiders - to distinguish between its own members and those otherwise normally regarded as belonging to the same national or religious entity. (p. 7)

DiTommaso (2011:230) says that apocalyptic otherness expresses itself trilaterally as (1) the essential other, the opponent, (2) the opposite of the opponent, but also inseparable from it and (3) in relationship with the transcendent reality. DiTommaso (2011:231) emphasises that the apocalyptic thinkers also saw themselves as the chosen and elect of God, necessitating the view that everything has an opposite. ${ }^{11}$

The literary corpus of the Qumran community is characterised by certain themes and tendencies. It mounts a polemic against the priestly establishment in Jerusalem (García Martínez 2007c:75), and the underlying theology of most of the texts entails radical dualism (García Martínez 2007c:98; cf. also 2007a:204, 2007b), determinism and messianism or eschatology (García Martínez 2007f:9). This means that the Qumran community (sect) defined itself not only as the opponent of the 'Other' but also as elected by God (cf. Vermes 1997:87-109; Bockmuehl 2001:388-394). The understandable result of this kind of thinking is exclusive language. Being a sect that developed as a form of resistance (cf. García Martínez 2007b:43) against the practices of its time, the community's strong emphasis on exclusivism is seen in almost all the texts in this corpus. These texts are interspersed with exclusive language, and this exclusive discourse was used to create the community's identity and to separate it from any other form of Judaism. ${ }^{12}$ A few texts (Jubilees, Community Rule and the Damascus Document) ${ }^{13}$ will be discussed as examples. ${ }^{14}$

9.See inter alia Barr (ed. 2006), Bauckham (2001), Baumgarten (1997:167-180), Carson et al. (2001), Collins (1986, 1988), Collins $(1997,1998)$, Flusser (2007) and Russel (1964) for an in-depth discussion of apocalyptic literature and thoughts.

10.For a discussion on the sects in Judaism, see Baumgarten (1997), Deines (2001), Talmon (1994:11-14, 17-18) and Vermes (1977:116-156).

11.See DiTommaso (2011), Freyne (2011), Raphael (2011) and Harlow (2011) for a discussion of how Apocalypticism led to creating an identity opposing the 'Other'.

12.See Berg (2014: 333-349) for a discussion on how the community created and maintained boundaries between themselves and the 'Other'.

13. Hengel (2000:50) refers to the last two documents specifically as the documents that depict the rules of entrance as well as the rules of exclusion: '... in the Rule of the Community, which emphasizes the role of the assembly, and the Damascus Document, where the role of the měbaqqēr is stressed. The entrance into the community was legally a private contract between the novice and the yahad. The jurisdiction of the community extended to the obligations under private law: the highest punishment community extended to the obligations under private law: the highest punish
was expulsion for life' (italics in original). See also García Martínez (2007d:188).

14.Please note that the thrust of this article is specifically to find 'exclusive language'. am familiar with the different debates with regard to the origin and 'sectarian character' of different Qumran texts as well as the fact that every text also has its 
Jubilees is quoted several times throughout the corpus, which could be an indication of its authoritative (rather than sectarian) status within the community. It describes the moment when YHWH established a covenant with Moses. This covenant is described with so much exclusive language that it seems as if the community was specially selected by $\mathrm{YHWH}$, leading to the exclusion of anyone who is not part of the community. ${ }^{15}$

The Damascus Document ${ }^{16}$ also describes the tedious process of becoming part of the community. This text is also known for its exclusive language whereby the community is described as having been singled out. The document can be divided into three parts. The first part describes the comprehensive rebuke to the community that forms an introduction to the consequent regulations. The second part contains legal norms that partly originated from biblical laws and are partly the community's halakhic interpretation of biblical laws. The third part contains an assortment of sectarian regulations. Of the three parts, the first and the last have the most sectarian characteristics and therefore also contain more exclusive language. ${ }^{17}$

I would like to highlight the exclusive discourse in selected texts from Community Rule (1QS). In Community Rule, the exclusive tone is very clear, indicating how the community members see themselves as exclusive and distant from those who are not part of the community. See the following examples in columns 3 and $5^{18}$ :

Col. iii (= 4Q255 2, 4Q257 iii, 4Q262 1) 1 his soul loathes the disciplines of knowledge of just judgments. He has not the strength to convert his life and shall not be counted with the upright. 2 His knowledge, his energy and his wealth shall not enter the council of the Community because he ploughs in the mud of wickedness and there are stains 3 on his conversion. He shall not be justified while he maintains the stubbornness of his heart, since he regards darkness as paths of light. In the source of the perfect 4 he shall not be counted. He will not become clean by the acts of atonement, nor shall he be purified by the cleansing waters, nor shall he be made holy by seas 5 or rivers, nor shall he

(footnote continues)

own context, emphasising not necessarily the same ideology or theology (see inter alia Baumgarten 1994; Collins 1998:145; Goodman 1995; Talmon 1994). Refer inte alia to Collins (1997:3), who reflects on the different kinds of theologies that developed or existed in the community. If the documents from the community represented a developing community or even more than one community, I also agree with García Martínez (2007f:9) that 'in view of the character of the Qumran Community it seems to me out of the question that it should have preserved and made use of works incompatible with its own ideology'. Harrington (2000:74) refers to this as follows: 'Scholars are now debating the number of communities behind the Scrolls and their dates and places of origin. However, with regard to behind the scrolls and their dates and places of origin. However, with regard to their biblical legal interpretations, the material shows much more consonance than dissonance. Therefore, I assume that for the scope of this article it is not ecessary to discen between the different texts with regard to their different content and intentions. Still, the selected texts will be either texts that were seen as texts with authority at Qumran (Jubilees and the Damascus Document) or part of the texts that are qualified by most scholars as sectarian (1QS). Also refer to
Baumgarten $(1997: 1$, fn. 1 ) for a discussion on the texts that are seen as sectarian.

15.Q216 - col. ii (= Jub 1:7-15): ' 9 ... And I shall hid[e] my [face] from them and will gi[ve them into the hand of the people]s for cap[tivity,] ... 15 [for devas]tation [and so they can be consumed. I will remove them from the midst of the land and scatter them among all the people[s.]' (García Martínez \& Tigchelaar 1999).

16.See Baumgarten (1997:21, fn. 62). He says that although it is not clear what the relationship between the Damascus Document and the Qumran community was, it is clear that the document was an integral part of the life of the community.

17.See García Martínez (2007c:83) for a discussion of the three sections that form part of the Damascus Document.

18. Except when stated otherwise, all translations were obtained from García Martínez and Tigchelaar (1999) be purified by all the water of ablution. Defiled, defiled shall he be all the days he spurns the decrees 6 of God, without allowing himself to be taught by the Community of his counsel. ..

19 ... From the spring of light stem the generations of truth, and from the source of darkness the generations of deceit. 20 And in the hand of the Prince of Lights is dominion over all the sons of justice; they walk on paths of light. And in the hand of the Angel of 21 Darkness is total dominion over the sons of deceit; they walk on paths of darkness. From the Angel of Darkness stems the corruption of 22 all the sons of justice, and all their sins, their iniquities, their guilts and their offensive deeds are under his dominion. (col. iii [= 4Q255 2, 4Q257 iii, 4Q262 1])

1 Blank This is the rule for the men of the Community who freely volunteer to convert from all evil and to keep themselves steadfast in all he commanded in compliance with his will. They should keep apart from the congregation of 2 the men of injustice in order to constitute a Community in law and possessions. (col. v [= 4Q261 1, cf. 4Q256 ix, 4Q258 i, ii])

From 1 QS vv. 22-23, it is clear that the community has seen itself as elected by God, as the true remnant of Israel,' 19 'to make understand the wisdom of the sons of heaven to those of perfect behaviour. For those God has chosen for an everlasting covenant 23 and to them shall belong all the glory of Adam'.

The community excluded themselves from the wickedness of the Other, and members were divided into ranks according to how 'pure' they were, and there were strict regulations for admitting a member into the community and governing their conduct. ${ }^{20}$

19.See García Martinez (2007d) for a detailed discussion on who the 'Other' was for the Qumran community.

20.Col. v ( $=4$ Q261 1, cf. 4Q256 ix, 4Q258 i, ii) (italics added): 'Whoever enters the council of the Community 8 enters the covenant of God in the presence of all who freely volunteer. He shall swear with a binding oath to revert to the Law of Moses, according to all that he commanded, with whole 9 heart and whole soul, in compliance with all that has been revealed of it to the sons of Zadok, the priests who keep the covenant and interpret his will and to the multitude of the men of their covenant 10 who freely volunteer together for this truth and to walk according to his will. He should swear by the covenant to be segregated from all the men of injustice who walk 11 along the path of wickedness. For they are the men of injustice who walk 11 along the path of wickedness. For they are not included in his covenant since they have neither sought nor examined his decrees in order to know the hidden matters in which they err 12 by their own fault and because they treated revealed matters with disrespect; this is why wrath will rise up for judgment in order to effect revenge by the curses of the covenant, in order to administer fierce 13 punishments for everlasting annihilation without there being any remnant. Blank ... 20 ... And when someone enters the covenant to behave in compliance with all these decrees, enrolling in the assembly of holiness, they shall examine 21 their spirits in the Community, one another, in respect of his insight and of his deeds in law, under the authority of the sons of Aaron, those who freely volunteer in the Community to set up 22 his covenant and to follow all the decrees which he commanded to fulfil, and under the authority of the majority of Israel, those who freely volunteer to return within the Community to his covenant. 23 And they shall be recorded in order, one before the other, according to one's insight and one's deeds, in such a way that each one obeys another, the junior the senior. And 24 their spirit and their deeds must be tested, year after year, in order senior. And 24 their spirit and their deeds must be tested, year after year, in orde to upgrade each one to the extent of his insight and the perfection of his path, or to demote him according to his failings. One should reproach 25 one another in truth, in meekness and in compassionate love for one's fellow-man'.

Col. vi (= 4Q256 xi, 4Q258 ii, iii, 4Q261 3, 4Q263) (italics added): ' 8 .... Blank This is the Rule for the session of the Many. Each one by his rank: the priests will sit down first, the elders next and the remainder of 9 all the people will sit down in order of rank. And following the same system they shall be questioned with regard to judgment, all counsel and any matter referred to the Many, so that each can impart his knowledge 10 to the council of the Community. Blank No-one should talk during the speech of his fellow before his brother has finished speaking. Blank And neither should he speak before one whose rank is listed 11 before his own. Whoever is questioned should speak in his turn. And in the session of the Many no-one should utter anything without the consent of the Many, save the 12 Inspector of the Many. And anyone who has something to say to the Many but is not in the position of one who is asking questions to the Community council, 13 that man should stand up and who is asking questions to the Community council, 13 that man should stand up and say: "I have something to say to the Many". If they tell him to, he should speak ...24 Blank And these are the regulations by which they shall judge in an examination of the Community depending on the case. If one is found among them who has lied 25 knowingly concerning possessions, he shall be excluded from the pure food of the Many for a year and they shall withhold a quarter of his bread. And whoever retorts to 26 his fellow with stubbornness, (and) speaks with brusqueness, ruining the footing he has with him, defying the authority of his fellow who is enrolled ahead of 
Newsom (2004:2) says that 'the Qumran community used language to constitute a world of meaning, a distinctive identity, a community of values, and a structure of selfhood'. It is clear that the Qumran community used exclusive language to dissociate themselves from the non-members and to emphasise their exclusiveness. García Martínez (2007d) explains this as follows:

$[T]$ he 'other' is completely excluded and must not have any relationship at all with it. The physical separation from the 'other', the move to the desert, is the ultimate consequence of the radical form of the sectarian self-understanding of the Community, for which every 'other' is wicked. (p. 217)

This exclusivity was supported by strict admission rules, a hierarchical order in the community and a possibility of expulsion from the community for transgressions.

\section{Exclusive language in Chronicles}

Jonker says (2010c) that:

[t]he Book of Chronicles represents a powerful identity formation discourse within Jerusalem and the province of Yehud. It therefore speaks 'inwards', towards the Jewish returnees who were in a process of restoration after the exile. (p. 604)

Geyser and Breytenbach (2006:494-497) argue that Chronicles can be seen as a discourse of power, legitimating the temple and its personnel. By emphasising the temple, ${ }^{21}$ the cult, the sacrifices and the service of the priests and the Levites, the economic welfare as well as the political power of the temple staff were guaranteed. The new history that Chronicles created is nothing other than a legitimation of a new ideology that favours and empowers the priests and the Levites. Consequently, they were also the elite, with decision-making powers over ordinary citizens. This was achieved especially by using exclusive language and also by selective narration. A few examples of how the author(s) of Chronicles created an exclusive discourse are given below. ${ }^{22}$

\footnotetext{
(footnote continues)

him, 27 [he $h$ ]as taken the law into his own hands; and he will be punished for on[e] year [... Who] ever enunciates the Name (which is) honoured above all'.

Col. vii (= 4Q259 i-ii, 4Q261 5,6, cf. 4Q265 1 i, 4Q266 10 ii, 4Q270 7 i; 11Q29 ?) (italics added): ' 1 whether blaspheming, or suddenly overtaken by misfortune or for any other reason, $\{\ldots\}$ or reading a book, or blessing, will be excluded 2 and shall not go back ever to the Community council. Blank And if he has spoken angrily against one of the priests enrolled in the book, he will be punished for one 3 year and shall be excluded, under sentence of death, from the pure food of the Many. However, if he had spoken unintentionally, he will be punished for six months. Blank And whoever lies knowingly 4 shall be punished for six months. Whoever knowingly and for no reason insults his fellow will be punished for a year 5 and will be excluded for no reason insults his fellow will be punished for a year 5 and will be excluded ...22 \{...\} However, anyone who has been in the Community council $\{. .$.$\} for ten full years.$ Blank 23 Blank $\{\ldots\}$ Blank and whose spirit reverts to betray the Community and go away from the presence Blank 24 of the Many in order to walk in the stubbornness of his heart, will never return to the Community council. And the person among the men of the Commu[nity w] ho fraternizes 25 with him with regard to his purity or his goods, wh[o ...] the Many, and his sentence will be like his, [he] shall be expe[lled ...]" Col. ix (= 4Q256 xviii, 4Q258 vii,viii, 4Q259 iii,iv, 4Q260 i) (italics added): '1 Because for $\{\ldots\}$ one sin of oversight he will be punished two years; but whoever acts impertinently shall not return again. Only someone who sins through oversight 2 shall be tested for two full years with respect to the perfectness of his behaviour and of his counsel according to the authority of the Many, and shall then be enrolled according to his rank in the Community of holiness. 3 Blank ... 14 ... Blank he should keep hold of the chosen ones of the period according to his will, as he has commanded; he should carry out the judgment of each man in accordance with his spirit; he should include each one according to the purity of his hands and according to his intellect 16 promote him'.

21.See Japhet (2009:50-64) for a discussion on YHWH's presence in the Temple as depicted in Chronicles.

22.These examples are a summary of an in-depth discussion by Geyser and Breytenbach (2006) and will be supported by referring to other scholars where applicable.
}

\section{Genealogies}

The author amended genealogies to include certain groups and exclude others. In 1 Chronicles 2:3, the focus is on the tribe of Judah, placing David in the middle of the genealogy. Therefore, the Bathsheba narrative is omitted (see Jonker 2013:49) in order to enhance David's image (see Jonker 2013:130) (the mother of Solomon is called Bat-Sua [See Klein 2006:115]). For the same reason, the Juda-Tamar narrative is omitted (see Klein 2006:114-116 and Jonker 2013:44, 130) (from Judah came Jesse, David's father). These two omitted narratives are good examples of silenced voices. Jesse's sons were renumbered in such a way that David became the seventh, seven being the ideal number, instead of the eighth (see Dirksen 2005:52). Abraham and Moses are not mentioned either, because they were associated with the northern kingdom and none of them ever lived in or even visited Jerusalem. The tribes of Judah (see Knoppers 2003:302), Benjamin and Levi receive preference, and the temple personnel and their duties are emphasised.

\section{Ideal identity for David}

Not only in the genealogies (see Knoppers 2003:302, 331) but also in the narrative part about the kings, David is emphasised. He is portrayed as the ideal king, the patron of the temple, and this required an ideal identity (Blenkinssop 2013):

There was a place in his ideal polity for a restored Davidic kingship, but only if it met the needs of the community for which he wrote and supported the operation of the temple cult on which, for the author, everything else depended. In order to meet these needs the author of Chronicles set about constructing his own image of David as founder and patron of the guilds with the greatest freedom from the constraints of tradition. (pp. 112-113)

The kings are judged by their involvement in the Jerusalem temple cult and are compared with the ideal identity that was created around David. He had priestly functions and blessed people in the name of YHWH (1 Chr 15:1-16, 43). His successes, richness, power and popularity are specifically mentioned (1 Chr 12:23-40, 1 Chr 22:14). He received his kingship directly from YHWH (1 Chr 10:14; 2 Chr 6:6). His last days are described positively. (In 1 Kings 1:1-4, he is described as old and weak, without any power. He was old and cold, they had to cover him with blankets and get a young girl to keep him warm.) In 1 Chronicles 29:10-20, he stands and offers a prayer of praise, whilst the whole gathering praised $\mathrm{YHWH}$ and bowed before him and David. It is obvious that specific parts of the source texts were omitted in Chronicles in order to put David in a favourable light (see Knoppers 2004:958). All but one of David's transgressions that are mentioned in the books of Samuel and Kings are omitted in Chronicles. The only unfavourable reference to David in the book pertains to the census he undertook (1 Chr 21:1, $1 \mathrm{Chr} 22: 1)$. The reason is the outcome, namely the indication of the site chosen for building the temple (2 Chr 3:1). This implies that in Chronicles, David was 
important because of his involvement with the temple; but his importance is less than that of the temple. ${ }^{23}$

\section{Moses and Abraham are underemphasised}

YHWH's covenant with Moses is not mentioned, as he is associated with Shechem (Dt 27) and is a symbol of the northern kingdom. YHWH is not described as the Lord who led them out of Egypt (see Japhet 2009:296). David established the cult - like Moses was commanded to do by YHWH. There are only selective references to Moses in the entire book of Chronicles. Unlike in the Pentateuch, Abraham is totally minimised in Chronicles. Abraham's covenant with YHWH is not mentioned either, because he is associated with Mount Gerizim, where Isaac's sacrifice would have taken place. Mount Gerizim is seen as the place of the Samaritans. YHWH is not described as the Lord of Abraham, Isaac and Jacob; the patriarchal covenant is not important in Chronicles. ${ }^{24}$ These traditions are clearly silenced in Chronicles.

\section{Solomon, who had the temple built, is portrayed positively}

Whereas Samuel and Kings describe the rebellion of Absalom, who wanted to kill his own brother, and Adonijah, who declared himself king, Chronicles omits all of this, stating that all the king's sons made an oath of faith towards King Solomon. There are also similarities between David and Solomon. Both were appointed by $\mathrm{YHWH}$, and both reigned for 40 years. Solomon ascended the throne in David's presence and with the blessing of the whole nation. YHWH blessed him exceedingly (1 Chr 29:25; see also 2 Chr 1:1). With a chiastic pattern, Solomon's wealth and greatness are emphasised (2 Chr 9:13a). Knoppers (2004:957) says that Solomon's reign is depicted by Chronicles as 'unparalleled by those who went before him'.

\section{Comparing Chronicles and selected Qumran texts}

It is clear that Chronicles uses exclusive language in the form of emphasising and underemphasising (silenced voices) in order to depict one specific ideology, namely that there is only one legitimate YHWH worship and that is in the temple of Jerusalem. Japhet (2009) emphasises this as follows:

The principle of exclusivity finds its positive expression in the proper establishment and maintenance of legitimate $\mathrm{YHWH}$ worship ... it necessitates the abolition of any other form of YHWH ritual - and, first and foremost, the destruction of local places of worship, 'the high places'. (p. 170)

The selected Qumran texts show how the community used exclusive language in order to distance themselves from, firstly, the Jerusalem temple cult and, secondly, any other

23.Dirksen (2005:256) explains it as follows: "[N]ot the census but the place of the temple forms the purpose of the chapter'.

24.Knoppers (2004:645) emphasises that these narratives are not important in Chronicles.
Judaic sect (see García Martínez 2007d:216). The community consisted of ranks according to pureness; they excluded themselves from the 'sons of darkness' and had strict regulations for admitting new members into the community and governing their conduct.

It is clear that authors in quite diverse contexts (Qumran and Chronicles) used exclusive language to establish a world of meaning for their recipients and to create a distinctive identity.

In the next section, I briefly touch on other post-exilic texts that used exclusive language on their path to identity finding.

\section{Exclusive language in other Old Testament texts}

As it will not be possible to describe all the Old Testament books that used exclusive language in detail, I will refer briefly to some scholarly research already done in this regard.

Ezra and Nehemiah are viewed by most scholars as books of exclusivity. ${ }^{25}$ Ezra 10 and Nehemiah 13 deal with mixed marriages. Both chapters state that all foreign wives and children from these marriages were chased out of Jerusalem. In Nehemiah 13:23-25, it is clear that there was no tolerance at all:

23 In those days also I saw Jews who had married women of Ashdod, Ammon, and Moab; 24 and half of their children spoke the language of Ashdod, and they could not speak the language of Judah, but spoke the language of various peoples. 25 And I contended with them and cursed them and beat some of them and pulled out their hair; and I made them take an oath in the name of God, saying, 'You shall not give your daughters to their sons, or take their daughters for your sons or for yourselves'. (New Revised Standard Version)

These texts have been referred to as 'texts of terror'. ${ }^{26}$ Their exclusive language creates an exclusivist Jewish identity. These texts are a polemic against foreign nations.

According to Eskenazi (2014):

[Ezra-Nehemiah] indicates that diverse groups and nationalities now lived under a single umbrella and at the service of an empire. Whatever community was gathering in Judah/Yehud, it was small, mostly poor, and itself diverse, surrounded by other groups. [Ezra-Nehemiah] can be read as a response to such challenges in which identity is no longer given, no longer automatically established by virtue of geographical location or even genealogy ... [Ezra-Nehemiah] shows that identity needs to be assessed and (re)defined within a panoply of existing options and categories, as well as diverse constituencies; it also shows that conclusions need to be re-evaluated as times go on. (p. 231)

Jonker (2010c:601-602) also refers to Esther ${ }^{27}$ as being exclusive, saying that ' $[i] \mathrm{t}$ is clear that this narrative wanted to criticise

25. Refer to Breytenbach and Van wyk's (2001) article with regard to the situation that is portrayed in these books, with specific reference to the conflict situation.

26.Jonker (2010c:601) says that this term was coined by Phyllis Trible in her publication Texts of Terror: Literary-Feminist Readings of Biblical Narratives (Philadelphia: Fortress, 1984).

27.See also Macchi (2014) for a discussion on the 'powerful others' in the book of Esther. 
any anti-Jewish sentiment in the empire and wanted to claim support from the Persian emperor in this regard'.

In the following section, I briefly refer to a few post-exilic texts that in fact used inclusive language.

\section{Inclusive language in a few post-exilic texts}

Most scholars agree on the inclusiveness of the Book of Ruth (see Jonker 2010c:603, Wetter 2014 and Cohn 2014). Cohn (2014) says that Ruth is:

a quiet, domestic tale in which tolerance and openness flourish, and no one says a mean word ... a Moabite widow is transformed into a proper Israelite matron ... Ruth offered a counterview to the more chauvinistic perspectives in the books of Ezra and Nehemiah ... Ruth made a claim for a shift in the national memory to undergird a wider Israelite identity. (p. 163)

Gillmayr-Bucher (2014:207) says that the 'other' in the book of Jonah is definitely the city Nineveh; and Jonker (2010c:602) points out that this book has an inclusive tone. GillmayrBucher (2014:218) emphasises this saying, 'Any idea of domination or exercising power is exclusively left to $\mathrm{YHWH}^{\prime}$. Jonker (2010c:603) considers Deutero- and Trito-Isaiah as well as Malachi as books that can also be seen to be inclusive.

In the few examples that we have discussed concerning inclusive language, it seems that these texts not only were in the minority but were also possibly contra-texts, polemically directed against the major texts that were interspersed with exclusive language.

\section{South Africa's context}

The question remains whether South Africa is truly democratic after 21 years of democratic elections. Breytenbach (2015) states this as follows:

The success of the liberal South African democracy is dependent on the support for the constitution amongst the voters. In the last few years, various political commentators across the spectrum have warned that the South African miracle is imploding and prominent South Africans have expressed concern that South Africa is a failing state, inter alia because the interest of political parties is put above the values expressed in the constitution. (p. 4)

Bentley (2014) gives an overview of how undemocratic South Africa is with regard to the disparities between the rich and the poor. He says that South Africa is one of the countries with the 'greatest economic divide among its population'. He also refers to the abuse of power in South Africa:

$[T]$ he country has seen wave after wave of government scandals ranging from misappropriation of public funds, the abuse of power for material gain, an arms deal scandal, a scandal involving the building of a presidential residence at excessive cost to the public and increasing events of police brutality. (p. 1)

After 21 years of democratic elections and with a democratic constitution, it still seems that South Africa cannot succeed in being truly democratic. Although the constitution provides for freedom of speech and equal opportunities, it seems that South Africa is marked as a country where those in positions of power abuse it to enrich themselves.

\section{Conclusion}

It is clear that all communities use exclusive language under certain circumstances to strengthen a certain group's identity and to empower them; to legitimise this group's conduct, behaviour and claims; and to exclude other groups in the process. The question might be asked whether it is really wrong for a confused nation to create an identity for itself. The answer will be 'no' in most contexts. The problem arises when they exclude others from God's 'salvation' and love by believing that they possess the only truth and that they are the only ones worthy of his grace.

Although the concepts of 'exclusive language' and 'power discourses' were introduced by postmodern philosophers, such language has been used almost spontaneously through all ages. Every time it was used to create identity and to empower (vs. overpower) - we can say that it is almost part of being human.

History also shows that wherever people find themselves in a position of power $^{28}$ they tend to abuse that power and they do this especially by using exclusive language to empower themselves, to legitimise their conduct and to create or strengthen their identity. South Africa is no exception. In post-1994 South Africa, these questions will need to be answered, however: What should be done to be democratic, and what language should be used? How can a truly democratic identity be created in a country of diversity?

In this study, it became clear that a few texts have used inclusive language in order to oppose other texts and their use of exclusive language to support their views on an exclusive identity. An inclusive discourse might be the only way by which exclusive language can be contradicted, and it might help in attaining a truly democratic country.

Inclusive language is respectful. An inclusive discourse is accepting of everyone, irrespective of the person's background, through mutual respect and no harm caused to one another. This respect is empowering without being overpowering; it gives equal opportunities without attempting to equalise. Everyone's identity must be cherished in a mosaic of diversity, without trying to force a certain culture or behaviour onto another. The basic requisition for mutual respect is to value the fact that everyone has an opinion, which creates a rich mosaic of differences. This goes beyond mere acknowledgement of differences; it is treating the differences with respect, not trying to level away all differences. Van Den Hoogen (2011:145) says that these are the actions of religious people, derived from a living relationship with the living God, and that these

28.See Macchi's (2014:219) question, "How much power is necessary to achieve one's goal, and where is the boundary between necessary use of power and a tyrannical use of power?' 
people 'live differently, and therefore speak differently'. 'A new life', he says, 'entails a new language game'.

\section{Acknowledgements Competing interests}

The author declares that she has no financial or personal relationships that may have inappropriately influenced her in writing this article.

\section{References}

Adams, S.A., 2014, Social and economic life in Second Temple Judea, John Knox Press, Westminster.

Barr, D.L. (ed.), 2006, The reality of apocalypse rhetoric and politics in the book of revelation, Society of Biblical Literature, Atlanta, GA.

Bauckham, R., 2001, 'Apocalypses', in D.A. Carson, P.T. O'Brien \& M.A. Seifrid (eds.), Justification and variegated nomism, vol. 1, The complexities of Second Temple Judaism, pp. 135-188, Mohr Siebeck, Tübingen.

Baumgarten, A.I., 1994, 'The rule of the Martian as applied to Qumran', Israel Oriental Studies $14,179-200$.

Baumgarten, A.I., 1997, The flourishing of Jewish sects in the Maccabean era: An interpretation, Brill, Leiden.

Benjamin, A. (ed.), 1992, Judging Lyotard, The University of Warwick, London.

Bentley, W., 2014, 'Methodism and transformation in South Africa: 20 years of constitutional democracy', HTS Teologiese Studies/Theological Studies 70(1), Art. \#2673, 8 pages. http://dx.doi.org/10.4102/hts.v70i1.2673

Ben Zvi, E. \& Edelman, D.V. (eds.), 2014, Imagining the Other and constructing Israelite identity in the early Second Temple period, Bloomsbury T\&T Clark, London.

Berg, S., 2014, 'Religious Epistemology and the History of the Dead Sea Scrolls Community', in E. Ben Zvi \& D.V. Edelman (eds.), Imagining the Other and
constructing Israelite identity in the early Second Temple period, Bloomsbury T\&T constructing Israel
Clark, London.

Beukes, J., 2012, 'Analitiese konsepte in middel-Foucault' [Analytic concepts in middle Foucault], HTS Teologiese Studies/Theological Studies 68(1), Art. \#1035, 17 pages. http://dx.doi.org/10.4102/hts.v68i1.1035

Beukes, J.C., 1996, 'Michel Foucault en die historisering van Anderswees' [Miche Foucault and the historization of otherness], HTS Teologiese Studies/Theologic Studies 52(2\&3), 233-251. http://dx.doi.org/10.4102/hts.v52i2/3.1496

Blenkinsopp, J., 2009, Judaism: The first phase. The place of Ezra and Nehemiah in the origins of Judaism, William B. Eerdmans Publishing Company, Cambridge.

Blenkinsopp, J., 2013, David remembered: Kingship and national identity in Ancient Israel, William B. Eerdmans Publishing Company, Cambridge.

Bockmuehl, M., 2001, '1QS and salvation at Qumran', in D.A. Carson, P.T. O'Brien \& M.A. Seifrid (eds.), Justification and variegated nomism, vol. 1, The complexities of Second Temple Judaism, pp. 381-414, Mohr Siebeck, Tübingen.

Bosman, H.L., 2014, 'The Exodus as negotiation of identity between memory and myth', HTS Teologiese Studies/Theological Studies 70(1), Art. \#2709, 6 pages. http://dx.doi.org/10.4102/hts.v70i1.2709

Bourdieu, P., 1991, Language and symbolic power, ed. L. Thompson, transl. G. Raymond \& M. Adamson, Polity Press, Cambridge.

Bourdieu, P., 1995, The rules of art genesis and structure of the literary field, transl. S. Emmanuel, Stanford University Press, Stanford, CA.

Brett, M.G., 2010, 'National identity as commentary and as metacommentary', in L.C. Jonker (ed.), Historiography and identity (re)formulation in Second Temple historiographical literature, pp. 29-40, T\&T Clark, New York.

Breytenbach, A.P.B. \& Van Wyk, W.C., Jr., 2001, 'The nature of conflict in EzraNehemiah', HTS Teologiese Studies/Theological Studies 57(3/4), 1254-1264. http://dx.doi.org/10.4102/hts.v57i3/4.1889

Breytenbach, C., 2015, 'Fundamental rights and religion: The space between cathedra and parliament', HTS Teologiese Studies/Theological Studies 71(1), Art. \#2989, 5 pages. $h$ ttp://dx.doi.org/10.4102/hts.v71i1.2989

Carson, D.A., O'Brien, P.T. \& Seifrid, M.A. (eds.), 2001, Justification and variegated nomism, vol. 1, The complexities of Second Temple Judaism, Mohr Siebeck, Tübingen.

Cohn, R.L., 2014, 'Overcoming otherness in the Book of Ruth', in E. Ben Zvi \& D.V. Edelman (eds.), Imagining the Other and constructing Israelite identity in the early Second Temple period, pp. 163-181, Bloomsbury T\&T Clark, London.

Collins, A.Y., 1986, 'Introduction: Early Christian apocalypticism', Semeia 36, 1-12.

Collins, A.Y., 1988, The Apocalypse, 5th print, Michael Glazier, Wilmington, DE.

Collins, J.J., 1997, Apocalypticism in the Dead Sea Scrolls, Routledge, New York.

Collins, J.J., 1998, The apocalyptic imagination: An introduction to Jewish apocalyptic literature, Eerdmans, Grand Rapids, MI.

Collins, J.J. \& Kugler, R.A. (eds.), 2000, Religion in the Dead Sea Scrolls, Wm. B. Eerdmaiis Publishing Co., Cambridge.
Deines, R., 2001, 'The Pharisees between "Judaisms" and "Common Judaism", in D.A. Carson, P.T. O'Brien \& M.A. Seifrid (eds.), Justification and variegated nomism, vol. 1 , The complexities of Second Temple Judaism, pp. 443-504, Mohr Siebeck, Tübingen.

Dews, P., 1984, 'The letter and the line: Discourse and its Other in Lyotard', JSTOR 14(3), 39-49.

Dirksen, P.B., 2005, 1 Chronicles, transl. A.P. Runia, Peeters, Leuven

DiTommaso, L., 2011, 'The apocalyptic Other', in D.C. Harlow, K.M. Hogan \& M.J. Goff (eds.), The 'Other' in Second Temple Judaism: Essays in honor of John J. Collins, pp. 221-246, Eerdmans, Cambridge.

Eskenazi, T.C., 2014, 'Imagining the Other in the construction of Judahite identity in Ezra-Nehemiah', in E. Ben Zvi \& D.V. Edelman (eds.), Imagining the Other and constructing Israelite identity in the early Second Temple period, pp. 230-256, Bloomsbury T\&T Clark, London.

Flusser, D., 2007, Judaism of the Second Temple, vol. 1, Qumran and apocalypticism, transl. A. Yadin, Eerdmans, Cambridge.

Foucault, M., 1977, Language, counter-memory, practice, Blackwell, Oxford.

Foucault, M., 1979, Discipline and punish: The birth of the prison, Peregrine Books, Middlesex.

Foucault, M., 1984, The history of sexuality, Peregrine Books, Middlesex.

Freyne, S., 2011, 'Apocalypticism as the rejected Other: Wisdom and apocalypticism in early Judaism and early Christianity', in D.C. Harlow, K.M. Hogan \& M.J. Goff (eds.), The 'Other' in Second Temple Judaism: Essays in honor of John J. Collins, (eds.), The 'Other' in Second Temple
pp. 247-261, Eerdmans, Cambridge.

García Martínez, F., 2007a, 'Apocalypticism in the Dead Sea Scrolls', in E.J.C. Tigchelaar (ed.), Qumranica Minora I. Qumran origins and apocalypticism, pp. 195-226, (ed.), Qumranica Minora I. Qumran origins and apocalypticism,
Studies on the Texts of the Desert of Judah, vol. LXIII, Brill, Leiden.

García Martínez, F., 2007b, 'A "Groningen" hypothesis of Qumran origins and early history', in E.J.C. Tigchelaar (ed.), Qumranica Minora I. Qumran origins and apocalypticism, pp. 31-52, Studies on the Texts of the Desert of Judah, vol. LXIII, Brill, Leiden.

García Martínez, F., 2007c, 'The history of the Qumran community in the light of recently available texts', in E.J.C. Tigchelaar (ed.), Qumranica Minora I. Qumran origins and apocalypticism, pp. 67-90, Studies on the Texts of the Desert of Judah, origins and apocalypticis
vol. LXII, Brill, Leiden.

García Martínez, F., 2007d, 'Invented memory: The "Other" in the Dead Sea Scrolls', in E.J.C. Tigchelaar (ed.), Qumranica Minora II. Thematic studies in the Dead Sea Scrolls, pp. 187-218, Studies on the texts of the Desert of Judah, vol. LXIV, Brill, Leiden.

García Martínez, F., 2007e, 'New perspectives on the study of the Dead Sea Scrolls', in F. García Martínez \& E.J.C. Tigchelaar (ed.), Qumranica Minora I. Qumran origin and apocalypticism, pp. 267-284, Studies on the Texts of the Desert of Judah, vol. LXIII, Brill, Leiden.

García Martínez, F., 2007f, 'Qumran origins and early history: A Groningen hypothesis', in E.J.C. Tigchelaar (ed.), Qumranica Minora I. Qumran origins and apocalypticism pp. 3-30, Studies on the Texts of the Desert of Judah, vol. LXIII, Brill, Leiden.

García Martínez, F., 2007g, Qumranica Minora I. Qumran origins and apocalypticism, E.J.C. Tigchelaar (ed.), Studies on the Texts of the Desert of Judah, vol. LXIII, Brill, Leiden.

García Martínez, F., 2007h, Qumranica Minora II. Thematic studies on the Dead Sea Scrolls, E.J.C. Tigchelaar (ed.), Studies on the Texts of the Desert of Judah, vol. LXIV, Brill, Leiden.

García Martínez, F. \& Tigchelaar E.J.C., 1999, The Dead Sea Scrolls study edition, Brill, Leiden.

Geyser, A.B. \& Breytenbach, A.P.B., 2006, '1 \& 2 Kronieke as 'n magsteks' [1 \& 2 Chronicles - A discourse of power], HTS Teologiese Studies/Theological Studies 62(2), 473-500.

Gillmayr-Bucher, S., 2014, 'Jonah and the Other: a discourse on interpretative competence', in E. Ben Zvi \& D.V. Edelman (eds.), Imagining the Other and constructing Israelite identity in the early Second Temple period, n.p., Bloomsbury T\&T Clark, London.

Goodman, M., 1995, 'A note on the Qumran sectarians, the Essenes and Josephus', Journal of Jewish Studies 46, 161-166.

Harlow, D.C., 2011, 'Idolatry and alterity: Israel and the nations in the "Apocalypse of Abraham"', in D.C. Harlow, K.M. Hogan \& M.J. Goff (eds.), The 'Other' in Second Temple Judaism: Essays in honor of John J. Collins, pp. 302-330, Eerdmans, Cambridge.

Harlow, D.C., Hogan, K.M., Goff, M. \& Kaminsky, J.S. (eds.), 2011, The 'Other' in Second Temple Judaism: Essays in honor of John J. Collins, Eerdmans, Cambridge.

Harrington, H.K., 2000, 'The Halakah and religion of Qumran', in J.J. Collins \& R.A. Kugler (eds.), Religion in the Dead Sea Scrolls, pp. 74-89, Wm. B. Eerdmaiis Publishing Co., Cambridge.

Hengel, M., 2000, 'Qumran and Hellenism', in J.J. Collins \& R.A. Kugler (eds.), Religion in the Dead Sea Scrolls, pp. 46-56, Wm. B. Eerdmaiis Publishing Co., Cambridge.

Japhet, S., 2009, The ideology of the Book of Chronicles and its place in biblical thought, Eisenbrauns, Winona Lake, IN.

Jonker, L.C., 2003, 'The rhetorics of finding a new identity in a multi-cultural and multireligious society', Verbum et Ecclesia 24(2), 396-416.

Jonker, L.C., 2010a 'David's officials according to the chronicler (1 Chr 23-27): A reflection of Second Temple self-categorization?', in L.C. Jonker (ed.), Historiography and identity (re)formulation in Second Temple historiographical literature, pp. 65-92, T\&T Clark, New York.

Jonker, L.C. (ed.), 2010b, Historiography and identity (re)formulation in Second Temple historiographical literature, T\&T Clark, New York. 
Jonker, L.C., 2010c. 'Human dignity and the construction of identity in the Old Testament', Scriptura 105, 594-607.

Jonker, L.C., 2013, 1 \& 2 Chronicles, Understanding the Bible Commentary series, Baker Books, Washington.

Keane, J., 1992, 'The modern democratic revolution: Reflections on Lyotard's "The Postmodern Condition"', in A. Benjamin (ed.), Judging Lyotard, pp. 81-98, The University of Warwick, London.

Klein, R., 2006, 1 Chronicles. A commentary, Fortress Press, Minneapolis.

Knoppers, G.N., 2003, 1 Chronicles 1-9: A new translation with introduction and commentary, The Anchor Bible, New York.

Knoppers, G.N., 2004, 1 Chronicles 10-29: A new translation with introduction and commentary, The Anchor Yale Bible, Yale.

Leuchter, M., 2010, 'Coming to terms with Ezra's many identities in Ezra-Nehemiah', in L.C. Jonker (ed.), Historiography and identity (re)formulation in Second Temple historiographical literature, pp. 41-64, T\&T Clark, New York.

Macchi, J., 2014, 'Denial, deception or force: How to deal with powerful others in the Book of Esther', in E. Ben Zvi \& D.V. Edelman (eds.), Imagining the Other and constructing Israelite identity in the early Second Temple period, pp. 219-229, Bloomsbury T\&T Clark, London.

Mitchell, C., 2010, 'Otherness and historiography in Chronicles', in L.C. Jonker (ed.) Historiography and identity (re)formulation in Second Temple historiographical literature, pp. 93-110, T\&T Clark, New York.

Newsom, C.A., 2004, The self as symbolic space: Constructing identity and community at Qumran, Brill, Leiden.

Nickelsburg, G.W.E., 2011, 'The We and the Other in the worldview of "1 Enoch," the Dead Sea Scrolls, and other early Jewish texts', in D.C. Harlow, K.M. Hogan \& M.J. Goff (eds.), The 'Other' in Second Temple Judaism: Essays in honor of John J. Collins, pp. 262-278, Eerdmans, Cambridge.
Perdue, L.G., 2005, Reconstructing Old Testament theology after the collapse of history, Fortress Press, Minneapolis.

Person, R.F., 2010, 'Identity (re)formation as the historical circumstances required', in L.C. Jonker (ed.), Historiography and identity (re)formulation in Second Temple historiographical literature, pp. 113-122, T\&T Clark, New York.

Raphael, R., 2011, 'Monsters and the crippled cosmos: Construction of the Other in Fourth Ezra', in D.C. Harlow, K.M. Hogan \& M.J. Goff (eds.), The 'Other' in Second Temple Judaism: Essays in honor of John J. Collins, pp. 279-301, Eerdmans, Cambridge.

Russell, D.S., 1964, The method and message of Jewish apocalyptic, 200 B.C.-100 A.D., John Knox Press, Westminster.

Schmitter, P.C., \& Karl, T.L., 1991, 'What Democracy Is...and Is Not', Journal of Democracy, Volume 2, Number 3, Summer 1991, pp. 75-88.

Snyman, G., 2010, 'Identity, power and the world of ancient (biblical) text production', in L.C. Jonker (ed.), Historiography and identity (re)formulation in Second Temple historiographical literature, pp. 133-148, T\&T Clark, New York.

Talmon, S., 1994, 'Qumran studies: Past, present and future', Jewish Quarterly Review 85, 1-31.

Trible, P., 1984, Texts of terror: Literary-feminist readings of biblical narratives, Fortress Press, Minneapolis, MN.

Van den Hoogen, T., 2011, A taste of God: On spirituality and reframing foundational theology, Nijmegen Studies in Theology, vol. 3, LIT, Berlin.

Van Zyl-Slabbert, F., 2006, The other side of history, Jonathan Ball, Cape Town.

Vermes, G., 1977, The Dead Sea Scrolls, Qumran in perspective, Fortress Press, Minneapolis, MN.

Wetter, A., 2014, 'Ruth: A born-again Israelite? One woman's journey through space and time', in E. Ben Zvi \& D.V. Edelman (eds.), Imagining the Other and constructing
Israelite identity in the early Second Temple period, pp. 144-162, Bloomsbury T\&T Clark, London. 